\title{
A comparison of the growth kinetics of six marine heterotrophic nanoflagellates fed with one bacterial species
}

\author{
Jacqueline D. Eccleston-Parry*, Barry S. C. Leadbeater \\ School of Biological Sciences, The University of Birmingham, PO Box 363, Birmingham B15 2TT, United Kingdom
}

\begin{abstract}
The growth kinetics of 6 species of marine heterotrophic nanoflagellates ( 5 to $13 \mu \mathrm{m})$ were compared. The maximum specific growth rates $\left(\mu_{\max }\right)$ of the flagellates ranged from 0.035 to $0.21 \mathrm{~h}^{-1}$ and the half-saturation constants $\left(K_{\mathrm{s}}\right)$ ranged from 1.1 to $45 \times 10^{6}$ bacterial cells $\mathrm{ml}^{-1}$ Theoretical threshold concentrations were calculated for each flagellate and the values of these generally ranged from 2 to $10 \times 10^{4}$ bacterial cells $\mathrm{ml}^{-1}$. The flagellate yield values $(Y)$, maximum uptake rates $\left(U_{\max }\right)$ and maximum clearance rates $\left(F_{\max }\right)$ for each flagellate species ranged from 0.3 to $13.2 \times 10^{-3}$ cells bacterium ${ }^{-1}, 5$ to 259 bacteria cell ${ }^{-1} \mathrm{~h}^{-1}$ and 1 to $58 \mathrm{nl}^{\mathrm{c}} \mathrm{cell}^{-1} \mathrm{~h}^{-1}$ respectively while volume-specific clearance values ranged from $1.4 \times 10^{4}$ to $8.7 \times 10^{5}$ body volumes $\mathrm{h}^{-1}$
\end{abstract}

KEY WORDS: Grazing B Batch culture Specific growth rate

\section{INTRODUCTION}

The heterotrophic nanoflagellates are ubiquitous in aquatic systems and comprise a mixed taxonomic assemblage (Patterson \& Larsen 1991). They are known to be the major consumers of picoplankton, capable of consuming $60 \%$ or more of the bacterial population (Sherr et al. 1986). They are also important agents of remineralization (Sherr et al. 1983, Goldman \& Caron 1985, Goldman et al. 1985, 1987, Andersen et al. 1986) providing a vital link between the 'microbial loop' (Azam et al. 1983) and the higher order food chain. Most studies have categorised all heterotrophic nanoflagellates as a single functional unit (HNAN) and they are continually referred to as a composite group whereas they actually comprise a mixture of very different species. It is therefore important to elucidate how and why so many species have managed to coexist with each other.

\footnotetext{
- Present address: Division of Biological Sciences, I.E.B.S. Lancaster University, Lancaster LA1 4YQ, UK
}

The persistence of a variety of heterotrophic nanoflagellate species within a very narrow size category ( 2 to $20 \mu \mathrm{m}$ ) will require them to occupy slightly different environmental niches in order to avoid exclusion from the particular habitat. Similar species are thought to compete more with each other than dissimilar species (Gause 1934) and so each nanoflagellate, being overall similar to the others in size, prey selection (i.e. bacterivorous) and prey utilization, has had to develop some form of survival strategy by which it is able to coexist with other species.

The physicochemical factors of an environment primarily govern the species composition of communities within a given location but the role of biotic factors such as inherent control mechanisms (intraspecies competition), interspecies competition and predatorprey interactions within the community are thought to be very important (Begon \& Mortimer 1987). Information on this subject in the field of heterotrophic nanoflagellates is limited at present.

Five distinct phases are recognised within the feeding process of phagotrophic nanoflagellates, namely searching, capture, ingestion, digestion and assimila- 
tion of the prey. These 5 phases encompass the potential for a range of possible variations which may have led to the development of different feeding strategies by different flagellate species. Each species may have different preferences for prey types especially with respect to the size range of acceptable prey. Large prey are thought to be preferentially grazed by raptorial feeders (Fenchel 1982a, Ammerman et al. 1984, Andersen et al. 1986) while filter feeders, e.g. choanoflagellates, are thought to feed preferentially on smaller bacteria due to size limitations of their filtration apparatus (Fenchel 1991). Some flagellates can consume a range of different-sized prey, for example, Paraphysomonas imperforata is known to consume bacteria $\left(0.5 \mu \mathrm{m}^{3}\right)$ and large algal cells $\left(200 \mu \mathrm{m}^{3}\right)$ (Goldman \& Caron 1985), while cell fusion is commonly seen in Ciliophrys marina cultures, providing a way in which cells can communally ingest prey larger than that which would be successfully attacked by individuals (Cienkowski 1870, Davidson 1982).

Of course, suitable prey may not always be available in the desired concentration or size range. Some flagellates can therefore resort to cannibalism (Fenchel 1982a, Goldman \& Caron 1985, Jonsson 1986), photoautotrophy (Sanders et al. 1990, Jones et al. 1993), cyst formation (Sherr et al. 1983) or a state of low metabolic growth (Fenchel 1982a) in times of starvation.

The aim of this investigation was to compare the growth kinetics of 6 species of heterotrophic nanoflagellates, all of which have relatively simple life cycles in culture. They are each quite distinct and yet their characteristics overlap to some degree. This is the first part of a larger-scale study on the elucidation of possible niche segregation among the heterotrophic flagellates. Later studies include the evaluation of other survival strategies, e.g. growth at low prey density, but for this first part, an initial comparison of the potential ability of each species to avoid competitive exclusion by other species was made.

\section{METHODS}

Heterotrophic nanoflagellates. Six species were selected for this study based on their size (5 to $13 \mu \mathrm{m}$ ) and feeding mechanisms. They included Paraphysomonas imperforata Lucas, Stephanoeca diplocostata Ellis and Codosiga gracilis James-Clark. Bodo designis Skuja and Jakoba libera (Ruinen) Patterson were supplied by D. J. Patterson (formerly of Bristol University, UK) and Ciliophrys infusionum Cienkowski was supplied by S. Tong (Southampton University, UK) (Fig. 1).

Bacterial prey. A bacterial strain was isolated from a coastal seawater sample from Plymouth, UK. It is

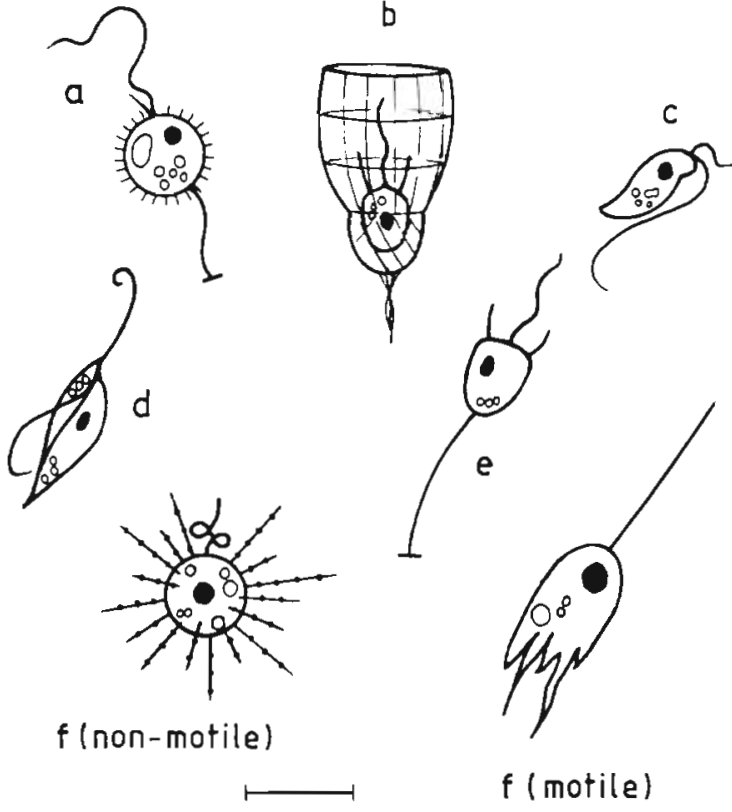

Fig. 1. The 6 species of heterotrophic nanoflagellate used in this study. (a) Paraphysomonas imperforata, (b) Stephanoeca diplocostata, (c) Bodo designis, (d) Jakoba libera, (e) Codosiga gracilis and (f) Ciliophrys infusionum. Scale bar $=10 \mu \mathrm{m}$

a Gram-negative, motile, rod-shaped bacterium 10.8 $\times 1.4$ to $1.8 \mu \mathrm{m}$ ) with a bivolume of approximately $0.67 \mu \mathrm{m}^{3}$. It has been tentatively identified by the National Collections of Industrial and Marine Bacteria Ltd, Aberdeen, UK, as a strain of the genus Alteromonas or Shewanella. Throughout this study, the bacterium, designated ' $\mathrm{B} 1$ ', is the sole bacterial strain used in experiments.

Maintenance of flagellate cultures. Clonal cultures of each flagellate were obtained from single-cell isolations (Hamilton \& Preslan 1969). Each species was serially diluted in artificial seawater (Harrison et al. 1980), microdrops from the higher dilutions were placed onto sterile slides and individual drops containing a single cell were enriched with $1 \%(\mathrm{w} / \mathrm{v})$ of a yeast extract/ proteose peptone mixture $\left(0.8 / 4.0 \mathrm{gl}^{-1}\right)$. After incubation at $20^{\circ} \mathrm{C}$ the individual drops containing numerous nanoflagellate cells were transferred to Erlenmeyer flasks containing a larger volume of enriched medium.

Indigenous bacteria in the 6 flagellate cultures were eliminated by the addition of 4 antibiotics which were active against Gram-negative bacteria, namely streptomycin-sulphate (final concentration $25 \mu \mathrm{g} \mathrm{ml}^{-1}$ ), gentamycin $\left(10 \mu \mathrm{g} \mathrm{ml}^{-1}\right)$, chloramphenicol (30 $\mu \mathrm{g} \mathrm{m}^{-1}$ ) and tetracycline $\left(100 \mu \mathrm{g} \mathrm{ml}^{-1}\right)$, and 1 antibiotic active against Gram-positive bacteria, namely penicillin G (100 units $\mathrm{ml}^{-1}$ ). Antibiotic susceptibility profiles of the indigenous bacteria indicated that these would eliminate all the bacterial strains present. Individual anti- 
biotic solutions were added separately to a stationary culture of each flagellate species with a few drops of the yeast extract-proteose peptone mixture and incubated at $20^{\circ} \mathrm{C}$. The separate addition of antibiotics avoided possible antagonistic reactions known to occur between certain antibiotics, e.g. chloramphenicol/tetracycline with penicillin G (Singleton \& Sainsbury 1981). Cultures were monitored for flagellate concentration using a haemocytometer and bacterial concentration, both viable, using the dilution plate technique, and total, using a haemocytometer. After $2 \mathrm{~d}$ incubation, those antibiotics active against Gramnegative bacteria, which appeared not to affect the flagellate concentration and motility but eliminated the bacteria, were prepared once again and added to the flagellate culture which had already been treated with penicillin $\mathrm{G}$. This culture was reincubated at $20^{\circ} \mathrm{C}$ until no bacteria were detectable ( 2 to $3 \mathrm{~d}$ ). Other workers who have also used mixed antibiotic treatments to remove indigenous bacteria include Daggett \& Nerad (1982), Jonsson (1986), Sherr et al. (1986) and Geider \& Leadbeater (1988).

A high density suspension of bacterium B1 was added to each flagellate culture and all were maintained monoxenically from then on. Every 5 d, subculturing was carried out in fresh medium supplemented with a standard volume of the yeast extract-proteose peptone solution ( $1 \%$ final concentration).

Flagellate grazing experiments. Kinetic data were obtained by monitoring the growth of each flagellate species in batch culture as a function of initial bacterium B1 concentration, using conventional experimental techniques. Bacterial suspensions were prepared by scraping off bacterium B1 in the stationary growth phase from Blood Agar Base plates (M.A.S.T. Laboratories, Bootle, UK) into artificial seawater. This stock suspension was enumerated with a haemocytometer using a relevant dilution which yielded 5 to 20 bacteria per small square $\left(2.5 \times 10^{-7} \mathrm{~mm}^{3}\right) ; 40$ squares were counted. The bacterial suspension, and selected dilutions, were added to $7 \times 30 \mathrm{ml}$ artificial seawater in $100 \mathrm{ml}$ Erlenmeyer flasks for each grazing experiment, to give initial bacterial concentrations ranging from $8 \times 10^{5}$ to $2.24 \times$ $10^{8}$ bacteria $\mathrm{ml}^{-1}$. Triplicate flasks were employed at each initial bacterial concentration. The bacterium did not grow in this medium; instead, the concentration slowly declined, with a half-life of about $105 \mathrm{~h}$.

A late-exponential culture of the flagellate was used to inoculate each flask. There was however some degree of carry-over of bacterium B1 from the flagellate inoculum into the experimental flasks. So, the actual initial bacterial concentration was corrected for, by further haemocytometer counts, after the addition of the flagellate culture to the Erlenmeyer flasks to give a starting concentration of 2000 flagellates $\mathrm{ml}^{-1}$.
Flasks were incubated at $20^{\circ} \mathrm{C}$ without shaking and, at predetermined intervals, a $2 \mathrm{ml}$ sample of each was fixed with $50 \mu \mathrm{l} 4 \%$ glutaraldehyde solution and vortexed. Both the flagellate species and bacterium B1 were enumerated using a haemocytometer and 4 haemocytometer counts were performed for each sample. These experiments were performed twice.

Calculations. The natural logarithm of flagellate concentration was plotted against time for each flagellate species at each initial bacterial concentration, and from this relationship, 4 numerical values were obtained for each system: (1) the specific growth rate, $\mu\left(\mathrm{h}^{-1}\right)$; (2) the highest concentration of flagellate achieved [in this paper referred to as peak abundance (cells $\mathrm{ml}^{-1}$ ) (cf. 'maximum population abundance' in Sherr et al. 1983)]; (3) the overall increase in flagellate concentration; and (4) the corresponding overall decrease in bacterial concentration. These 4 values were then used to determine the yield value and maximal values of specific growth rate, bacterial uptake rate and clearance rate of the flagellate species studied.

Specific growth rate, $\mu$, was calculated from regression analysis of the linear portion of the graph associated with the exponential phase of growth where the overall flagellate cell volumes remained constant and where there was only a slight decrease in bacterial concentration. This is viewed as the closest state to balanced growth obtainable in batch culture (Fenchel 1982a, Sherr et al. 1983, Andersen 1989).

The relationship between the specific growth rate of the flagellate and the initial bacterial concentration was fitted to a hyperbolic function of a form $\mu=$ $x \mu_{\max } /\left(K_{\mathrm{s}}+x\right)$ following Monod (1950), where $\mu=$ the specific growth rate as a function of initial bacterial concentration $(x)$, maximum specific growth rate $\left(\mu_{\max }\right)$ and the half-saturation constant $\left(K_{\mathrm{s}}\right)$. The parameters $\mu_{\max }$ and $K_{\mathrm{s}}$ were calculated by the least-squares method to fit the line $x=\mu_{\max }[x / \mu]-K_{s}$, where the gradient gave the $\mu_{\max }$ value and the intercept on the $y$-axis gave the $K_{\mathrm{s}}$ value.

Ciliophrys infusionum was the only species to exhibit a measurable threshold level of bacterial concentration for positive flagellate growth and, therefore, the relationship between $\mu$ and initial bacterial concentration was fitted to a modified hyperbolic function of the form $\mu=\mu_{\max }[x-t] /\left[\left(K_{\mathrm{s}}-t\right)+(x-t)\right]$ following Taylor (1978), where $t=$ the threshold concentration, the highest value of $x$ where $\mu$ is zero, which was estimated at $2 \times 10^{7}$ cells $\mathrm{ml}^{-1}$ by visual inspection of the graphical data. Determination of $\mu_{\max }$ and $K_{\mathrm{s}}$ were obtained by the least-squares method to fit the line $[x-t]=$ $\mu_{\max }[(x-t) / \mu]-\left[K_{\mathrm{s}}-t\right]$ (Taylor 1978).

The highest concentration of flagellate within each of the flasks, the peak abundance, was recorded and 
plotted against the initial bacterial concentration $\left(\log _{10}\right.$ axes). A linear relationship was obtained for each flagellate species for which an equation of the line was calculated by regression analysis. The equation was used to calculate a theoretical threshold bacterial concentration that exists for each of the flagellate species with this bacterium. It was assumed that if the initial flagellate population (2000 cells $\mathrm{ml}^{-1}$ ) exibited a zero growth rate, the final concentration would also be 2000 cells $\mathrm{ml}^{-1}\left(\log _{10} 3.3\right)$ assuming a negligible death rate. By inserting ' $y$ ' at 3.3 into the equations of the lines, a theoretical threshold bacterial concentration (' $x$ ') for each flagellate was calculated.

Observed yield $(Y)$ was calculated as the increase in flagellate concentration divided by the decrease in bacterial concentration ( $Y=$ highest minus initial flagellate concentration/initial minus lowest bacterial concentration; Pirt 1975) to give the number of flagellate cells produced upon the ingestion of 1 bacterial cell. This is similar to the method of Fenchel (1982a) whereby final flagellate concentration is divided by initial bacterial concentration, except that in our calculations, the initial flagellate concentration is taken into account and there is no assumption that all the prey are consumed. The method however assumes that all the energy obtained from ingested prey is being used for growth and reproduction, and not for maintenance (Fenchel 1982a).

Maximum uptake rate ( $U_{\max }$ bacteria flagellate $^{-1}$ $\mathrm{h}^{-1}$ ) was calculated as $U_{\max }=\mu_{\max } / 0.5 Y$ (following Fenchel 1982a), where $Y=$ flagellate yield. $Y$ had to be corrected to account for the number of divisions (usually 1) the flagellate underwent after the prey had fallen below the feeding threshold at the onset of the stationary phase (Fenchel 1982a).

The maximum clearance values $\left(F_{\max }\right.$, nl flagellate cell ${ }^{-1} \mathrm{~h}^{-1}$ ) were calculated, following Fenchel (1982a), from the equation $F_{\max }=U_{\max } / K_{\mathrm{s}}$. The volume-specific clearances $\left(\mathrm{h}^{-1}\right)$ were then calculated by dividing the maximum clearance rate by the volume $(V)$ of the flagellate. Volumes were determined from the equation $V=\pi\left(s^{2} l\right) / 6$, where $s$ is the shortest length of the protoplast and $l$ is the longest.

\section{RESULTS AND DISCUSSION}

\section{Description of the six heterotrophic nanoflagellates}

Paraphysomonas imperforata, Stephanoeca diplocostata and Codosiga gracilis had been maintained in the Birmingham University (UK) culture collection prior to this study. P. imperforata (Chrysophyceae) is spherical (diameter 5 to $10 \mu \mathrm{m}$ ) and the cell is covered with siliceous spines (Fig. 1a). The volume of growing cells was approximately $212 \mu \mathrm{m}^{3}$. It possesses 2 flagella, the longer having a bilateral array of 'heterokont' tubular hairs, the shorter being smooth. $P$. imperforata feeds by direct interception of suspended prey including bacteria, microalgae and other protists (Goldman \& Dennett 1990). Goldman \& Caron (1985) have shown that the cell volume of acceptable prey for $P$. imperforata can vary from $0.5 \mu \mathrm{m}^{3}$ (bacterial cells) to $200 \mu^{3}$ (Dunaliella tertiolecta cells). P. imperforata can be found swimming at speeds up to $42 \mu \mathrm{m} \mathrm{s}^{-1}$ or may be attached in large clusters to detritus or bacterial aggregates by a thin stalk originating from the posterior end of the cell. This species is ubiquitous in both marine and freshwater habitats. The protoplasts of $S$. diplocostata and $C$. gracilis (Choanoflagellida) are both of the size range 5 to $8 \mu \mathrm{m}$ with volumes of 35 and $83 \mu^{3}$ respectively. They possess a single flagellum encircled by a collar of tentacles (Fig. 1b, e). Both are filter feeders of bacteria in suspension (Sleigh 1964). C. gracilis is found attached by means of a stalk to bacterial clumps and detritus in marine environments. The protoplast of $S$. diplocostata is surrounded by a basketlike lorica composed of siliceous costae (Leadbeater 1979).

Bodo designis is elliptical in shape, measuring 5 to $10 \mu \mathrm{m}$ with 2 flagella inserted sub-apically (Fig. 1c), and has a volume of ca $54 \mu^{3}$. It has a characteristic 'corkscrew' swimming behaviour, reaching speeds of $80 \mu \mathrm{m} \mathrm{s}^{-1}$. The posterior flagellum is twice as long as the body and attaches to the substratum where bacteria are most commonly grazed. This species is known to occur in freshwater, marine and soil environments. The cell body of Jakoba libera (Ruinen) Patterson, formally Cryptobia libera Ruinen, is acutely obovate and measures 8 to $13 \mu \mathrm{m}$ in length (Fig. 1d) with a volume of ca $75 \mu \mathrm{m}^{3}$. The anterior flagellum is inserted apically and is held in a characteristic hook shape while the posterior flagellum is inserted slightly sub-apically. The posterior flagellum beats in a ventral groove in which bacterial prey becomes trapped and ingested. Cells can be found free swimming at speeds up to $19.2 \mu \mathrm{m} \mathrm{s}^{-1}$ or exhibiting jerking movements backwards and forwards. J. libera feeds on bacteria although it is unknown whether it has a preference for prey in suspension or attached to surfaces. It is known to occur in both marine and freshwater sediments, intertidal benthic sites and surface waters (Patterson 1990).

Ciliophrys infusionum (Helioflagellida) has 2 cell forms and measures 8 to $13 \mu \mathrm{m}$ (Fig. 1f) and has a volume of ca $220 \mu \mathrm{m}^{3}$. The sessile form resembles a heliozoan, feeding on bacteria and small protists in suspension by means of 'granular' tentacles over the entire body surface. Little is known about the kinetic behaviour of $C$. infusionum. Laboratory observations have shown that motile cells move towards the edge of a cul- 
a) Paraphysomonas imperforata

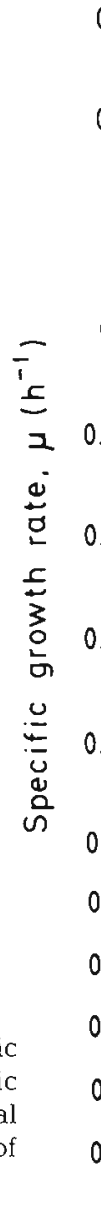

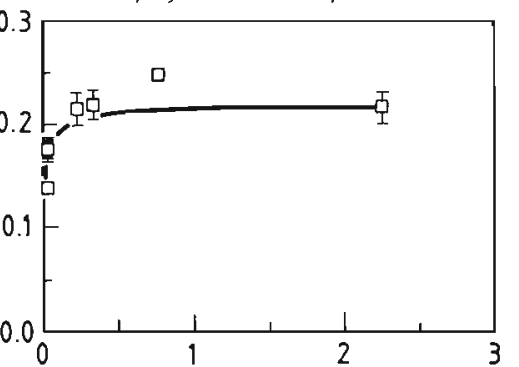

c) Codosiga gracilis
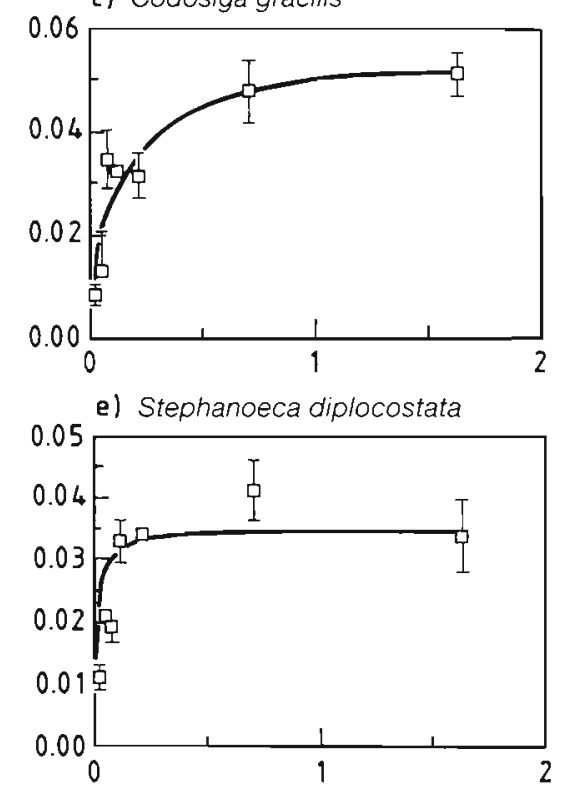

b) Bodo designis

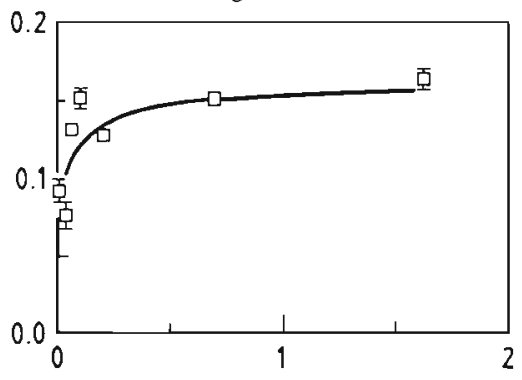

d) Ciliophrys infusionum

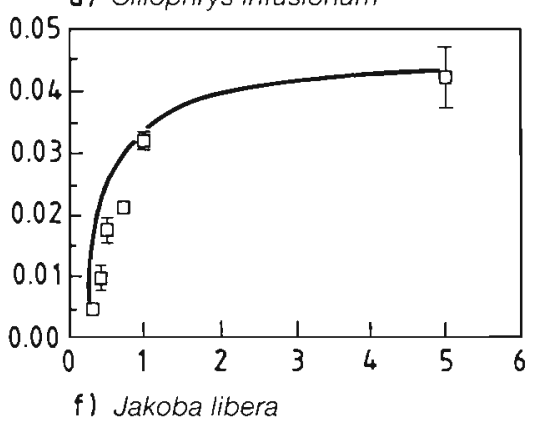

Fig. 2. A comparison of the hyperbolic relationship obtained from specific growth rate $(\mu)$ against initial bacterial concentration for each of the 6 species of heterotrophic nanoflagellate 
Table 1 . A comparison of the values of maximum specific growth rate $\left(\mu_{\text {max }} h^{-1}\right)$, half-saturation constant ( $K_{5}, 10^{6}$ bacteria ml ${ }^{-1}$ ) and yield $\left(Y, 10^{-3}\right.$ flagellate cells bacterium ') for various flagellate species and prey types. Temperature $=20^{\circ} \mathrm{C}$ unless otherwise stated. Results of this study in bold

\begin{tabular}{|c|c|c|c|c|c|c|}
\hline Flagellate & Prey & $\mu_{\mathrm{nld} \mathrm{x}}$ & $K_{\varsigma}$ & $Y$ & $1 / y$ & Source \\
\hline Actinomonas mirabilis & Pseudomonas sp. & 0.25 & 1.4 & 2.3 & 435 & Fenchel (1982b) \\
\hline Bodo designis & B1 & 0.16 & 3.4 & 2.0 & 500 & This study \\
\hline B. designis & Aeromonas sp. & 0.12 & 8.8 & - & - & Hammond (1991) \\
\hline B. edax & Klebsiella sp. & $0.116^{\mathrm{d}}$ & - & 6.7 & 150 & Dagget \& Nerad (1982) \\
\hline Ciliophrys infusionum & B1 & 0.045 & 45.0 & 0.3 & 3000 & This study \\
\hline Codosiga gracilis & B1 & 0.052 & 9.7 & 2.9 & 340 & This study \\
\hline Diaphanoeca grandis $\left(21^{\circ} \mathrm{C}\right)$ & Pseudomonas sp. & 0.12 & 2.4 & - & - & Andersen (1989) \\
\hline Jakoba libera & Aeromonas sp. & 0.08 & 5.3 & - & - & Hammond (1991) \\
\hline J. libera & B1 & 0.036 & 5.4 & 13.2 & 76 & This study \\
\hline Monosiga sp. & Pseudomonas sp. & 0.17 & 13.5 & 6.2 & 161 & Fenchel (1982a) \\
\hline Ochromonas sp. & Pseudomonas sp. & 0.19 & 19.0 & 10.0 & 100 & Fenchel (1.982a) \\
\hline Ochromonas sp $\left(18^{\circ} \mathrm{C}\right)$ & Natural assemblage & $0.016^{\circ}$ & - & 18.5 & 54 & Ammerman et al. (1984) \\
\hline Paraphysomonas vestita & Pseudomonas sp. & 0.23 & 14.9 & 0.9 & 1235 & Fenchel (1982a) \\
\hline P. imperforata & B1 & 0.21 & 1.1 & 6.6 & 152 & This study \\
\hline P. imperforata & Aeromonas sp. & 0.12 & 4.4 & - & - & Hammond (1991) \\
\hline P. imperforata & Vibriosp. & 0.22 & 13.0 & 1.7 & 606 & Edwards (1989) \\
\hline Pleuromonas jaculans & Pseudomonas sp. & 0.16 & 38.6 & 3.0 & 333 & Fenchel (1982a) \\
\hline Pseudobodo tremulans & Pseudomonas sp. & 0.15 & 8.4 & 1.8 & 555 & Fenchel (1982a) \\
\hline Stephanoeca diplocostatas $\left(18^{\circ} \mathrm{C}\right)$ & Pseudomonas sp. & 0.076 & 6.8 & 7.5 & 133 & Gelder \& Leadbeater (1988) \\
\hline S. diplocostata & Pseudomonas sp. & 0.063 & - & - & - & Leadbeater \& Davies (1984) \\
\hline S. diplocostata & Pseudomonas sp. & 0.031 & - & - & - & Leadbeater \& Davies (1984) \\
\hline S. diplocostata & B1 & 0.035 & 2.3 & 1.9 & 528 & This study \\
\hline Natural assemblage $\left(15^{\circ} \mathrm{C}\right)$ & Natural assemblage & $0.006^{\circ}$ & - & 2.7 & 366 & Bjornsen et al. (1988) \\
\hline Natural assemblage $\left(15^{\circ} \mathrm{C}\right)$ & Natural assemblage & $0.013^{a}$ & - & 3.7 & 271 & Bjornsen et al. (1988) \\
\hline Natural assemblage $\left(15^{\circ} \mathrm{C}\right)$ & Natural assemblage & 0.027 & - & 3.0 & 336 & Bjornsen et al. (1988) \\
\hline Natural assemblage (June) & Natural assemblage & $0.114^{\text {A }}$ & - & 28.5 & 35 & Bloem \& Bär-Gilissen (1989) \\
\hline Natural assemblage (August) & Natural assemblage & $0.068^{\dot{a}}$ & - & 96.0 & 10 & Bloem \& Bär-Gilissen (1989) \\
\hline
\end{tabular}

teria $\mathrm{ml}^{-1}$ ) to attain this value due to a threshold concentration of $2 \times 10^{7}$ bacteria $\mathrm{ml}^{-1}$ (Fig. $2 \mathrm{~d}$ ). The halfsaturation constant $\left(K_{s}\right)$ (Table 1 ) was 5 to 40 times higher than those recorded for the other species $(45 \pm$ $2.16 \times 10^{6}$ bacteria $\left.\mathrm{ml}^{-1}\right)$. P. imperforata, $B$. designis and $S$. diplocostata had comparable affinities for this bacterium $\left(K_{\mathrm{s}}\right.$ values of $1.1 \pm 2.1,3.4 \pm 1.3,2.3 \pm 1.9 \times$ $10^{6}$ bacteria $\mathrm{ml}^{-1}$ respectively), followed by $J$. libera $\left(5.4 \pm 1.2 \times 10^{6}\right.$ bacteria $\left.\mathrm{ml}^{-1}\right)$ and $C$. gracilis $(9.7 \pm 3.7$ $\times 10^{6}$ bacteria $\mathrm{ml}^{-1}$ )

A comparison of these results with those of other workers for the same and other flagellate genera (Table 1) reveals that these kinetic values are variable, which is possibly due to inherent (genetic) differences, the different prey species used, in some cases due to different experimental protocols, for example the effect of stirring (Leadbeater \& Davies 1984) and also due to different statistical analysis procedures. Our results are of the same order as most of the results obtained by others for the same taxa.

$K_{\mathrm{s}}$ is a parameter that can be used to compare the competitiveness of different flagellate species for the same limited resource in batch culture (Taylor 1978) but so too is the relationship between $\mu$ and initial bacterial concentration (Fenchel 1982a). Minimal variation in specific growth rates, at different initial bacterial concentrations, has been observed for the 6 flagellate species in subsequent experimentation; values are highly conserved. Comparison of the functional responses (Fig. 2) revealed that Paraphysomonas imperforata, Bodo designis and Ciliophrys infusionum did not have any overlapping specific growth rate values; the hyperbolic relationship for each species was quite distinct. The other 3 species, Codosiga gracilis, Jakoba libera and Stephanoeca diplocostata, did however have overlapping specific growth rates (Fig. 3). A crossover point, corresponding to the initial bacterial concentration at which the specific growth rate values of the 2 species involved were equal, was determined: $x=\left[\left(\mu_{\max 1} K_{\mathrm{s} 2}\right)-\left(\mu_{\max 2} K_{\mathrm{s} 1}\right)\right] /\left(\mu_{\max 2}-\mu_{\max 1}\right)$, where 1 and 2 represent species 1 and 2 respectively (Table 1 ).

Jakoba libera and Codosiga gracilis have a crossover value at $4.2 \times 10^{6}$ bacteria $\mathrm{ml}^{-1}$ (Fig. 3) and therefore below this initial bacterial concentration, $J$. libera has 


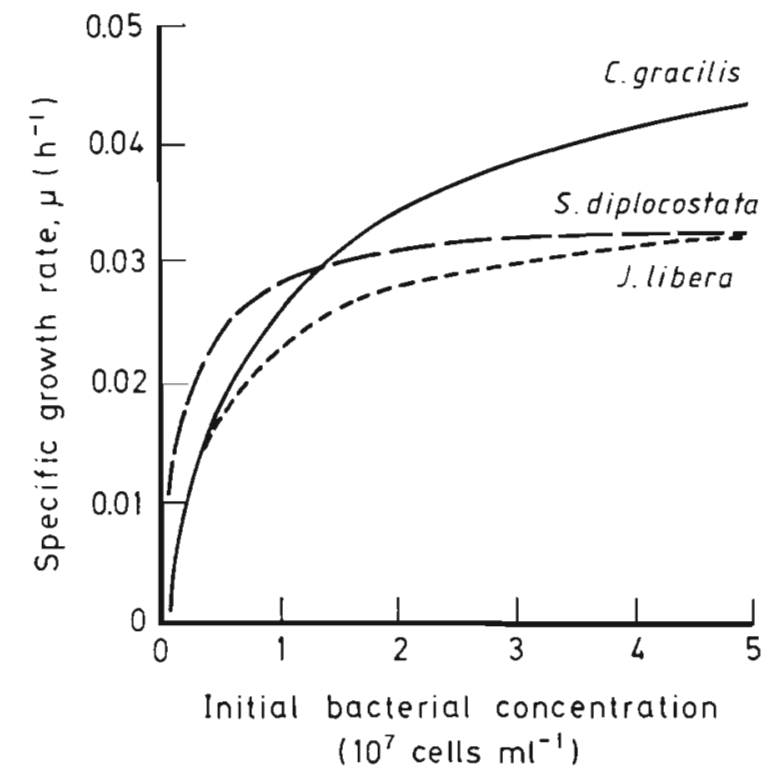

Fig. 3. Jakoba libera, Stephanoeca diplocostata and Codosiga gracilis. Overlapping characteristics in the relationship between specific growth rate and initial bacterial concentration

the higher value for $\mu$ whilst above this concentration, C. gracilis has the higher $\mu$ value. Stephanoeca diplo-

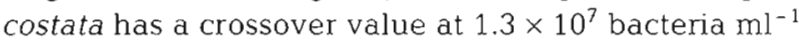
with C. gracilis. Therefore, at natural bacterial concentrations, which normally range from 0.5 to $2 \times 10^{6}$ bacteria $\mathrm{ml}^{-1}$ (Hagström et al. 1979) the behaviour of each flagellate species in relation to another is quite different from that assumed by comparison of $\mu_{\max }$ values only (Table 1). However, since the degree of error associated with the variable area of the hyperbolic function is relatively high, these predictions are not absolute but give an idea as to when different species would be likely to compete with each other.

\section{Flagellate peak abundance and bacterial threshold levels}

The linear relationships between $\log _{10}$ flagellate peak abundance and $\log _{10}$ initial bacterial concentration for each flagellate are shown in Fig. 4 while the equations of these lines are presented in Table 1 . The actual data points in Fig. 4 have been omitted for reasons of clarity but all the data fitted well to a straight line relationship, with the standard error of the regresssion coefficient, i.e. the gradient, being within the acceptable limit of an order of 10 below the regression coefficient value (Table 1).

The determination of a threshold density for Ciliophrys infusionum was relatively easy as it was so large (Fig. 2d), but for other species, the threshold density may be too small to be observed and so these values were calculated mathematically. The theoretical threshold concentration for $C$. infusionum was calculated mathematically as $1.32 \times 10^{7}$ bacteria $\mathrm{ml}^{-1}$ (Table 1), which was close to the value estimated by visual inspection (Fig. 2d). Thresholds have also been determined by recording the minimum number of bacteria at the onset of flagellate stationary phase in batch culture, i.e. when the predator can no longer graze the prey (Caron et al. 1985, Goldman et al. 1985, Goldman \& Dennett 1990). However, at this point in the growth cycle, the number of flagellate cells is increased and severe intraspecies competition for limited prey would be evident (Børsheim \& Bratbak 1987, Geider \& Leadbeater 1988). Some degree of partial refuge must be afforded to the prey in order for them to regenerate new cells and hence new food particles for the flagellate, and therefore a threshold level must exist. Sizeselective predation amongst heterotrophic flagellates may also be an effective mechanism for allowing bacterial refuge from predation (Chrzanowski \& Simek 1990 ) in addition to that obtained below the flagellate threshold feeding densities, although that was not investigated here.

The theoretical threshold values for 5 flagellate species ranged from 2.0 to $9.9 \times 10^{4}$ bacteria $\mathrm{ml}^{-1}$ (Table 2). These appear to be low values but the biovolume of bacterium $\mathrm{B} 1$ is approximately $0.67 \mu \mathrm{m}^{3}$ which is larger than natural bacterioplankton bio-

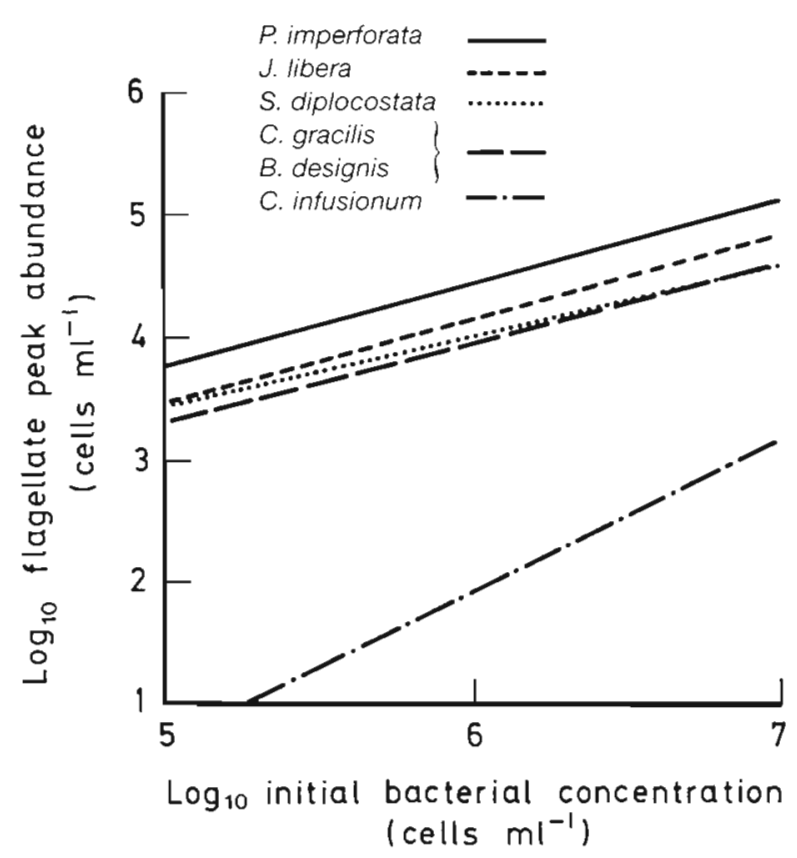

Fig. 4. Fitted lines for flagellate peak abundance against initial bacterial concentration for the 6 species of heterotrophic flagellate 
Table 2. The equations of the lines for flagellate peak abundance against initial bacterial concentration, the theoretical threshold concentrations and volume-specific clearance

\begin{tabular}{|lcrc|}
\hline Flagellate & $\begin{array}{c}\text { Equation of line }( \pm \mathrm{SE} \\
\text { regression coefficient) }\end{array}$ & $\begin{array}{c}\text { Threshold conc. } \\
\left.\text { (bacteria } \mathrm{ml}^{-1}\right)\end{array}$ & $\begin{array}{c}\text { Volume-specific } \\
\text { clearance }\left(10^{5} \mathrm{~h}^{-1}\right)\end{array}$ \\
\hline Paraphysomonas imperforata & $y=0.4551+0.6625 \times(0.04178)$ & $2.0 \times 10^{4}$ & 2.97 \\
Bodo designis & $y=0.0871+0.6432 \times(0.03828)$ & $9.9 \times 10^{4}$ & 8.71 \\
Codosiga gracilis & $y=0.2232+0.6238 \times(0.0685)$ & $8.6 \times 10^{4}$ & 0.45 \\
Ciliophrys infusionum & $y=-5.5020+1.2360 \times(0.0750)$ & $1.3 \times 10^{7}$ & 1.98 \\
Stephanoeca diplocostata & $y=0.5709+0.5729 \times(0.05846)$ & $5.8 \times 10^{4}$ & 4.58 \\
Jakoba libera & $y=-0.2825+0.7363 \times(0.0526)$ & $7.3 \times 10^{4}$ & 0.14 \\
\hline
\end{tabular}

volumes. Therefore, the threshold densities calculated here may be a misrepresentation and threshold densities pertaining to natural environments could be as much as an order of magnitude higher than those presented in Table 1. This would be in line with the results of Rivier et al. (1985) who observed thresholds for Pseudobodo sp. ranging from 9.5 to $187 \times 10^{5}$ bacteria $\mathrm{ml}^{-1}$ using mixed bacterial assemblages as the prey source. However, a threshold values will always be overestimates because they are consistent with the fact that a minimum food level represents the point at which the energy required for growth balances basal metabolic activity (Goldman \& Dennett 1990).

\section{Flagellate yield, uptake rate and clearance rate}

The yield values for the 6 flagellate species are presented in Table 1 and are of the same order except for Ciliophrys infusionum and Jakoba libera. J. libera had the highest yield value $\left(Y=13.2 \pm 4.78 \times 10^{-3}\right.$ flagellate cells bacterium ${ }^{-1}$ ), requiring only 76 bacterial cells ( $\left.1 / y\right)$ to produce 1 of its own whilst $C$. infusionum had the lowest yield value ( $Y=0.3 \pm 0.05 \times 10^{-3}$ flagellate cells bacterium $^{-1}$ ), requiring almost 3000 bacterial cells to produce 1 of its own. All the other results range from 1.9 to $6.6 \times 10^{-3}$ flagellate cells bacterium ${ }^{-1}$ or the requirement of between 153 and 526 bacterial cells to produce 1 flagellate cell. All the values, except for $C$. infusionum, fall into the range obtained by other workers, i.e. $0.9 \times 10^{-3}$ (Paraphysomonas vestita; Fenchel $1982 \mathrm{a}$ ) to $18.5 \times 10^{-3}$ flagellate cells bacterium $^{-1}$ (Ochromonas danica; Ammerman et al. 1984) (Table 1). Values obtained for mixed flagellate cultures preying on mixed bacterial prey in natural systems also have a large range, 2.7 to $96.0 \times 10^{-3}$ flagellate cells bacterium $^{-1}$ (Table 1 ).

Jakoba libera appears to be the most efficient feeder followed by Paraphysomonas imperforata, Codosiga gracilis, Bodo designis and Stephanoeca diplocostata and this bears no relationship to the other parameters discussed (Table 1). The term 'feeder' is an elusive term as we cannot determine at present which of the phases in the feeding process are determinants of efficiency. For example, little is known about the way in which P. imperforata captures and engulfs prey (Goldman \& Dennett 1990) even though this species has been studied intensively. However, Seale et al. (1990) found, from video recordings, that Spumella sp. captured about 60 bacteria $\mathrm{h}^{-1}$ but only ingested half that number (20 to 30 bacteria $\mathrm{h}^{-1}$ ).

Bacterial uptake per flagellate per unit time $(U)$ is a hyperbolic function of initial bacterial concentration (Fenchel 1982a, Davies \& Sieburth 1984, Goldman \& Caron 1985, Geider \& Leadbeater 1988, Andersen 1989 ) and the maximum uptake rate $\left(U_{\max }\right)$ effectively measures the maximum rate at which prey is ingested by the flagellate (Fenchel 1982a). Ciliophrys infusionum took up the most bacteria per hour (259; Table 3) followed by Bodo designis (160 bacteria $\mathrm{h}^{-1}$ ) and Paraphysomonas imperforata ( 63 bacteria $\mathrm{h}^{-1}$ ). Values for Stephanoeca diplocostata and Codosiga gracilis were comparable ( 37 and 36 bacteria $\mathrm{h}^{-1}$ ) but greater than for Jakoba libera ( 5 bacteria $\mathrm{h}^{-1}$ ).

Clearance $(F)$ quantifies the ability to concentrate food particles. Fenchel (1982a) considers this the most meaningful measure of the competitive ability of an organism as a grazer of suspended particles in nature. Paraphysomonas imperforata had the highest maximum clearance value (Table 3) followed by Bodo designis, Stephanoeca diplocostata, Ciliophrys infusionum, Codosiga gracilis, then Jakoba libera.

There was no true relationship between the values of $U_{\max }$ and $F_{\max }$ and the size of the flagellate; the largest flagellate (Ciliophrys infusionum) had the largest $U_{\max }$ but not the largest $F_{\max }$. The smallest flagellate (Stephanoeca diplocostata) did not have the smallest $U_{\max }$ or $F_{\text {max }}$. An appropriate comparison of flagellates can be made from volume-specific clearance rates (Table 2) (Fenchel 1982a, 1986) although the accuracy of these values is questionable since they are based on the volume of growing cells which is often difficult to calculate with a great degree of accuracy (Fenchel \& Finlay 1983). However, comparison of the results shows that Bodo de- 
Table 3. Comparison of specific growth rate $(\mu)$, uptake rate $(U)$ and clearance rate $(F)$ values of heterotrophic nanoflagellates. All experiments performed at temperatures of 20 to $24^{\circ} \mathrm{C}$ unless otherwise stated. Results of this study in bold

\begin{tabular}{|c|c|c|c|c|}
\hline $\begin{array}{l}\text { Heterotrophic flagellate } \\
\text { Prey species }\end{array}$ & $\stackrel{\mu}{\mu}$ & $\begin{array}{c}U \\
\left.\text { (bacteria } h^{-1}\right)\end{array}$ & 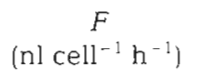 & Source \\
\hline \multicolumn{5}{|l|}{ Acanthoeopsis sp. } \\
\hline Vibrio $\mathrm{sp}$ & - & 136 & 9 & Davies \& Sieburth (1984) \\
\hline \multicolumn{5}{|l|}{ Actinomonas mirabilis } \\
\hline Pseudomonas sp. & $0.25^{\mathrm{a}}$ & $107^{\mathrm{i}}$ & $79^{\mathrm{a}}$ & Fenchel (1982b) \\
\hline Vibrio sp. & - & 224 & $160-203$ & Davies \& Sieburth (1984) \\
\hline \multicolumn{5}{|l|}{ Bodo sp. } \\
\hline Vibriosp. & - & $50-250$ & $19-120$ & Davies \& Sieburth (1984) \\
\hline Pseudomonas fluorescens & - & $3-5$ & $0.2-0.4$ & Chrzanowski \& Simek (1990) \\
\hline P. fluorescens & - & $11-44$ & $2-8$ & Chrzanowski \& Simek (1990) \\
\hline P. fluorescens & - & $2-7$ & $0.4-1$ & Chrzanowski \& Simek (1990) \\
\hline \multicolumn{5}{|l|}{ Bodo edax } \\
\hline Klebsiella pneumoniae (?) & 0.12 & 25 & - & Daggett \& Nerad (1982) \\
\hline \multicolumn{5}{|l|}{ Bodo celer } \\
\hline Vibrio sp. & - & 137 & 39 & Davies \& Sieburth (1984) \\
\hline \multicolumn{5}{|l|}{ Bodo designis } \\
\hline Vibrio sp. & - & $40-220$ & $32-57$ & Davies \& Sieburth (1984) \\
\hline Aeromonas aerogenes & 0.12 & - & - & Hammond (1991) \\
\hline B1 & $0.16^{\mathrm{a}}$ & $160^{\mathrm{a}}$ & $47^{\mathrm{a}}$ & This study \\
\hline \multicolumn{5}{|l|}{ Ciliophrys infusionum } \\
\hline B1 & $0.045^{\mathrm{a}}$ & $259^{a}$ & $6^{\mathrm{a}}$ & This study \\
\hline \multicolumn{5}{|l|}{ Ciliophrys sp. } \\
\hline Inert fluorescent particles & - & - & 5 & Tobiesen (1990) \\
\hline \multicolumn{5}{|l|}{ Codosiga gracilis } \\
\hline B1 & $0.052^{\mathrm{a}}$ & $36^{\mathrm{a}}$ & $4^{\mathrm{a}}$ & This study \\
\hline \multicolumn{5}{|l|}{ Diaphanoeca grandis } \\
\hline Pseudomonas sp. $\left(15^{\circ} \mathrm{C}\right)$ & $0.15^{\mathrm{a}}$ & $40^{\mathrm{a}}$ & $16^{\mathrm{a}}$ & Andersen (1989) \\
\hline Pseudomonas sp. & $0.19^{\mathrm{a}}$ & - & $25^{a}$ & Andersen (1989) \\
\hline \multicolumn{5}{|l|}{ Jakoba libera } \\
\hline Aeromonas aerogenes & 0.08 & - & - & Hammond (1991) \\
\hline B1 & $0.036^{\mathrm{a}}$ & $5^{\mathrm{a}}$ & $1^{\mathrm{a}}$ & This study \\
\hline \multicolumn{5}{|l|}{ Monas sp. } \\
\hline Chlorobium phaeobacteriodes & 0.11 & $11-44$ & $0.3-1$ & Sherr et al. (1983) \\
\hline Unidentified isolate & 0.128 & $50-75$ & $0.2-0.3$ & Sherr et al. (1983) \\
\hline Escherichia coli & 0.119 & $37-75$ & $0.2-0.6$ & Sherr et al. (1983) \\
\hline Salmonella typhimurium & 0.089 & $22-25$ & $0.07-0.5$ & Sherr et al. (1983) \\
\hline Vibrio sp. & - & -240 & $14-63$ & Davies \& Sieburth (1984) \\
\hline Vibrio sp. & - & $60-275$ & $38-336$ & Davies \& Sieburth (1984) \\
\hline Vibrio sp. & - & 173 & 20 & Davies \& Sieburth (1984) \\
\hline \multicolumn{5}{|l|}{ Monosiga sp. } \\
\hline Pseudomonas sp. & $0.17^{\mathrm{a}}$ & $27^{\mathrm{a}}$ & $2^{a}$ & Fenchel (1982a) \\
\hline \multicolumn{5}{|l|}{ Ochromonas danica } \\
\hline Pseudomonas fluorescens & - & $1.8-33$ & $0.1-2$ & Chrzanowski \& Simek (1990) \\
\hline \multicolumn{5}{|l|}{ Ochromonas sp. } \\
\hline Pseudomonas sp. & $0.19^{\mathrm{a}}$ & $190^{\mathrm{d}}$ & $10^{\mathrm{a}}$ & Fenchel (1982a) \\
\hline \multicolumn{5}{|l|}{ Oikomonas sp. } \\
\hline Vibrio sp. & - & $50-300$ & $28-65$ & Davies \& Sieburth (1984) \\
\hline \multicolumn{5}{|l|}{ Paraphysomonas imperforata } \\
\hline Phaeodactylum tricornutum & 0.062 & $7^{a}$ & $2^{\mathrm{a}}$ & Goldman \& Dennett (1990) \\
\hline P. tricornutum & 0.10 & - & 5.4 & Goldman \& Caron (1985) \\
\hline P. tricornutum & $0.087-0.10$ & $2.66^{\alpha}$ & $3.96-10.4$ & Caron et al. (1985) \\
\hline P. tricornutum & $0.083-0.11$ & $1-2$ & $1-7$ & Goldman et al. (1987) \\
\hline P. tricornutum & $0.088-0.14$ & $1-2^{d}$ & - & Andersen et al. (1986) \\
\hline Dunaliella tertiolecta & 0.064 & $2^{d}$ & $1.17^{\mathrm{a}}$ & Goldman \& Dennett (1990) \\
\hline D. tertiolecta & $0.082-0.10$ & $0.2-0.4$ & $0.4-2$ & Goldman et al. (1987) \\
\hline D. tertiolecta & 0.1 & - & 5 & Goldman \& Caron (1985) \\
\hline
\end{tabular}


Table 3 (continued)

\begin{tabular}{|c|c|c|c|c|}
\hline $\begin{array}{l}\text { Heterotrophic flagellate } \\
\text { Prey species }\end{array}$ & $\begin{array}{c}\mu \\
\left(h^{-1}\right)\end{array}$ & $\begin{array}{c}U \\
\left(\text { bacteria } h^{-1}\right)\end{array}$ & $\begin{array}{c}F \\
\text { (nl cell } \\
-1 \\
\left.\mathrm{~h}^{-1}\right)\end{array}$ & Source \\
\hline \multicolumn{5}{|l|}{ Paraphysomonas imperforata (continued) } \\
\hline Isochrysis galbana & 0,062 & $3^{\text {a }}$ & $3^{\mathrm{a}}$ & Goldman \& Dennett (1990) \\
\hline 1. galbana & 0.1 & - & 13 & Goldman \& Caron (1985) \\
\hline Chlorella stigmataphora & 0.1 & - & 4 & Goldman \& Caron (1985) \\
\hline C. capsulata & 0.096 & - & 11 & Goldman \& Caron (1985) \\
\hline Porphyridium sp. & 0.1 & - & 4 & Goldman \& Caron (1985) \\
\hline Vibrio sp. & - & -180 & $18-145$ & Davies \& Sieburth (1984) \\
\hline Pseudomonas halodurans & 0.10 & $23-118^{\alpha}$ & $2-4^{a}$ & Caron et al. (1985) \\
\hline Pseudomonas sp. & 0.10 & $21^{\mathrm{d}}$ & - & Andersen et al. (1986) \\
\hline Mixed bacteria & 0.14 & $70^{\mathrm{\alpha}}$ & - & Andersen et al. (1986) \\
\hline Aeromonas aerogenes & $0.12^{\alpha}$ & - & - & Hammond (1991) \\
\hline Vibriosp. & $0.21-0.22^{\mathrm{a}}$ & $249-278^{\mathrm{a}}$ & $19-21^{a}$ & Edwards (1989) \\
\hline B1 & $0.21^{\mathrm{a}}$ & $63^{\mathrm{a}}$ & $58^{a}$ & This study \\
\hline \multicolumn{5}{|l|}{ Paraphysomonas vestita } \\
\hline Pseudomonas sp. & $0.23^{d}$ & $254^{\mathrm{a}}$ & $17^{a}$ & Fenchel (1982a) \\
\hline \multicolumn{5}{|l|}{ Pleuromonas jaculans } \\
\hline Pseudomonas sp. & $0.16^{\mathrm{a}}$ & $54^{a}$ & $1.4^{\mathrm{a}}$ & Fenchel (1982a) \\
\hline \multicolumn{5}{|l|}{ Pseudobodo tremulans } \\
\hline Pseudomonas sp. & $0.15^{d}$ & $84^{4}$ & $10^{a}$ & Fenchel (1982a) \\
\hline Vibrio sp. & - & $10-300$ & $20-165$ & Davies \& Sieburth (1984) \\
\hline \multicolumn{5}{|l|}{ Pseudobodosp. } \\
\hline Natural $\left(15^{\circ} \mathrm{C}\right)$ & $0.08-0.16^{\mathrm{a}}$ & $4.5-85.4$ & $0.2-4$ & Rivier et al. (1985) \\
\hline \multicolumn{5}{|l|}{ Rhynchomonas sp. } \\
\hline Vibrio sp. & - & $30-210$ & $17-37$ & Davies \& Sieburth (1984) \\
\hline \multicolumn{5}{|l|}{ Spumella sp. } \\
\hline Xenorhabdus luminescens & 0.22 & $20-30$ & $10-62$ & Seale et al. (1990) \\
\hline \multicolumn{5}{|l|}{ Stephanoeca diplocostata } \\
\hline Pseudomonas sp. (stirred) $\left(18^{\circ} \mathrm{C}\right)$ & $0.079^{a}$ & $21^{\mathrm{a}}$ & $3^{\circ}$ & Geider \& Leadbeater (1988) \\
\hline Pseudomonas sp. (stirred) & 0.063 & - & - & Leadbeater \& Davies (1984) \\
\hline Pseudomonas sp. (unstirred) & 0.031 & - & - & Leadbeater \& Davies (1984) \\
\hline B1 & $0.035^{\mathrm{a}}$ & $37^{\mathrm{a}}$ & $16^{\mathrm{a}}$ & This study \\
\hline Maximum values & & & & \\
\hline
\end{tabular}

signis clears the largest number of body volumes and would therefore be expected to be an avid competitor for bacterial prey. S. diplocostata had the second highest value, even though it was the smallest flagellate, however, the existence of a basket-like siliceous lorica around the protoplast may in some way have increased the organism's efficiency of prey capture by increasing the surface area and overall volume of the cell. Paraphysomonas imperforata had a higher volume-specific clearance rate than Ciliophrys infusionium, followed by Codosiga gracilis and Jakoba libera

Acknowledgements. This study was supported by grant number GR3/7605 from the Natural Environmental Research Council. We thank Prof. D. J. Patterson, Mr S. Hammond and Miss S. Tong for supplying 3 of the flagellate species, Mr S. Price for his technical assistance, Ms P. Hill for preparing the figures and anonymous reviewers for their useful comments on the manuscript.

\section{LITERATURE CITED}

Ammerman, J. W., Fuhrman, J. A., Hagström, §., Azam, F. (1984). Bacterioplankton growth in seawater. Mar. Ecol. Prog. Ser. 18: 31-39

Andersen, O. K., Goldman, J. C., Caron, D. A., Dennett, M. R. (1986). Nutrient cycling in a microflagellate food chain: III. Phosphorus dynamics. Mar. Ecol. Prog. Ser. 31: 47-55

Andersen, P. (1989). Functional biology of the choanoflagellate Diaphanoeca grandis Ellis. Mar Microb. Fd Webs 3: 35-50

Azam, F, Fenchel, T., Field, J. G., Gray, J. S., Meyer-Reil, L. A., Thingstad, F. (1983). The ecological role of water column microbes in the sea. Mar. Ecol. Prog. Ser 10: 257-263

Begon, M. E., Mortimer, A. M. (1987). Population ecology. Blackwell, Oxford

Bjørnsen, P. K., Riemann, B., Horsted, S. J., Nielsen, T. G., PockSten, J. (1988). Trophic interactions between heterotrophic nanoflagellates and bacterioplankton in manipulated seawater enclosures. Limnol. Oceanogr. 33: 409-420

Bloem, J., Bär-Gilissen, M. -J. B. (1989). Bacterial activity and protozoan grazing potential in a stratified lake. Limnol. Oceanogr. 34: 297-309 
Borsheim, K. Y., Bratbak, G. (1987). Cell volume to carbon conversion factors for a bacterivorous Monas $\mathrm{sp}$. enriched from seawater. Mar. Ecol. Prog. Ser. 36: 171-175

Caron, D. A., Goldman, J. C., Andersen, O. K., Dennett, M. R. (1985). Nutrient cycling in a microflagellate food chain: Ul Population dynamics and carbon cycling. Mar. Ecol. Prog Ser. 24: 243-254

Chrzanowski, T H., Simek, K. (1990). Prey-size selection by freshwater flagellated protozoa. Limnol. Oceanogr. 35: $1429-1436$

Cienkowski, L. (1875). Über Palmellaceen und einige Flagellaten. Arch Mikrosk. Anat. Entwicklungsmech. 12: 15-50

Daggett, P.-M., Nerad, T A. (1982). Axenic cultivation of Bodo edax and Bodo uncinatus and some observations on feeding rate in monoxenic culture. J. Protozool. 29: $290-291$

Davidson, L. A. (1982). Ultrastructure, behaviour, and algal flagellate affinities of the helioflagellate Ciliophrys marina and the classification of the helioflagellates (Protista, Actinopoda, Heliozoea). J. Protozool 29: 19-29

Davies, P. G., Sieburth, J. McN. (1984). Estuarine and oceanic microflagellate predation of actively growing bacteria: estimation by frequency of dividing-divided bacteria. Mar. Ecol. Prog. Ser. 19: 237-246

Edwards, A. M. (1989). Heterotrophic chrysophytes; their role in energy and carbon turnover in the sea. Ph.D. thesis, University of Birmingham

Fenchel, T (1982a). Ecology of heterotrophic microflagellates. II. Bioenergetics and growth. Mar. Ecol. Prog. Ser. 8 $225-231$

Fenchel, T. (1982b). The bioenergetics of a heterotrophic microflagellate. Annls Inst. océanogr. 58: 55-60

Fenchel, T. (1986). Protozoan filter feeders. Prog. Protistol. 1: $65-113$

Fenchel T. (1991). Flagellate design and function. In: Patterson, D. J., Larsen, J. (eds.) The biology of free-living heterotrophic flagellates. The Systematics Association special volume No 45, Clarendon Press, Oxford, p. 7-19

Fenchel, T. Finlay, B. J. (1983). Respiration rates in heterotrophic free-living protozod. Microb. Ecol 9: 99-122

Gause, G. F. (1934). The struggle for existence. Williams \& Wilkins, Dover

Geider, R. J., Leadbeater, B. S. C. (1988). Kinetics and energetics of growth of the marine choanoflagellate Stephanoeca diplocostata. Mar. Ecol. Prog. Ser. 47 169-177

Goldman, J. C., Caron, D. A. (1985). Experimental studies on an omnivorous microflagellate: implications for grazing and nutrient regeneration in the marine microbial food chain. Deep Sea Res. 32: 899-915

Goldman, J. C., Caron, D. A., Andersen, O. K., Dennett, M. R. (1985). Nutrient cycling in a microflagellate food chain: I. Nitrogen dynamics. Mar. Ecol. Prog. Ser. 24: 231-242

Goldman, J. C., Caron, D. A., Dennett, M. R. (1987). Nutrient cycling in a microflagellate food chain: IV. Phytoplanktonmicroflagellate interactions. Mar. Ecol. Prog. Ser. 38: $75-87$

Goldman, J. C., Dennett, M. R. (1990). Dynamics of prey selection by an omnivorous flagellate. Mar. Ecol. Prog Ser. 59: 183-194

Hagström, A., Larsson, U., Horstedt, P., Normark, S. (1979) Frequency of dividing cells, a new approach to the determination of bacterial growth rates in aquatic environments. Appl. environ. Microbiol. 37: 805-812

Hamilton, R. D., Preslan, J. E. (1969). Cultural characteristics of a pelagic marine hymenostome ciliate, Uronema sp J. exp. mar. Biol. Ecol. 4: 90-99
Hammond, S. J. (1991). Comparative growth characteristics of heterotrophic flagellates. M.Sc. thesis, Bristol University, p. $26-37$

Harrison, P. J., Waters, R. E., Taylor, F. J R. (1980). A broad spectrum artificial seawater medium for coastal and open ocean phytoplankton. J. Phycol. 16: 28-35

Jones, H. L. J., Leadbeater, B. S. C., Green, J. C. (1993). Mixotrophy in a marine species of Chrysochromulina: ingestion of a small green flagellate. J. mar. biol. Ass. U.K. 73: $283-296$

Jonsson, P. R. (1986). Particle size selection, feeding rates and growth dynamics of marine planktonic oligotrichous ciliates (Ciliophora: Oligotrichina). Mar. Ecol. Prog. Ser. 33: $265-277$

Leadbeater, B. S. C. (1979). Developmental studies on the loricate choanoflagellate Stephanoeca diplocostata Ellis. I. Ultrastructure of the non-dividing cell and costal strip production. Protoplasma 98: 241-262

Leadbeater, B. S. C., Davies, M. E. (1984). Developmental studies on the loricate choanoflagellate Stephanoeca diplocostata Ellis. III. Growth and turnover of silica, preliminary observations. J. exp. mar. Biol. Ecol. 81: 251-268

Monod, J. (1950). La technique de la culture continue: théorie et applications. Annls Inst. Pasteur, Lille 79: 390-410

Patterson, D. J. (1990). Jakoba libera (Ruinen, 1938) a het erotrophic flagellate from deep oceanic sediments. J. mar biol. Ass. U.K. 70: 381-393

Patterson, D. J., Larsen, J. (1991). General introduction. In Patterson, D. J., Larsen, J. (eds.) The biology of free-living heterotrophic flagellates. The Systematics Association special volume No. 45. Clarendon Press, Oxford, p. 1-5

Pirt, S. J. (1975). Principles of microbe and cell cultivation Blackwell, London, p. 4-14

Rivier, A., Brownlee, D. C., Sheldon, R. W., Rassoulzadegan, F. (1985). Growth of microzooplankton: a comparative study of bacterivorous zooflagellates and ciliates. Mar. microb. Fd Webs 1: 51-60

Sanders, R. W., Porter, K. G., Caron, D. A. (1990). Relationship between phototrophy and phagotrophy in the mixotrophic chrysophyte Poterioochromonas malhamensis. Microb. Ecol. 19: 97-109

Seale, D. B., Boraas, M. E., Holen. D., Nealson, K. H. (1990). Use of bioluminescent bacteria, Xenorhabdus luminescens, to measure predation on bacteria by freshwater microflagellates. FEMS Microbiol. Ecol. 73: 31-40

Sherr, B. F., Sherr, E. B., Andrew, T. L., Fallon, R. D., Newell, S. Y (1986). Trophic interactions between heterotrophic protozoa and bacterioplankton in estuarine water analysed with selective metabolic inhibitors. Mar. Ecol. Prog. Ser. 32: 169-179

Sherr, B. F., Sherr, E. B., Berman, T (1983). Grazing, growth, and ammonium excretion rates of a heterotrophic microflagellate fed with four species of bacteria. Appl. environ. Microbiol. 45: 1196-1201

Singleton, P., Sainsbury, D. (1981). Dictionary of microbiology. John Wiley \& Sons, New York

Sleigh, M. A. (1964). Flagellar movement of the sessile flagellates Actinomonas, Codonosiga, Monas and Poteriodendron. Q. J. microsc. Sci. 105: 405-415

Taylor, W. D. (1978). Growth responses of ciliate protozoa to the abundance of their bacterial prey. Microb. Ecol. 4: $207-214$

Tobiesen, A. (1990). Temperature dependent filtration rates and size selection in some heterotrophic microflagellates and some dinoflagellates. Arch. Hydrobiol. Beih. 34 293-304

Manuscript first received: May 28, 1993

Revised version accepted: December 3, 1993 